\title{
Economic Uncertainty and the Demand for Broad Money in South Africa
}

\author{
Wen-Hsien Tan \\ Faculty of Economics and Business, Universiti Malaysia Sarawak \\ 94300 Kota Samarahan, Sarawak, Malaysia \\ Chin-Hong Puah (Corresponding author) \\ Faculty of Economics and Business, Universiti Malaysia Sarawak \\ 94300 Kota Samarahan, Sarawak, Malaysia \\ E-mail: chpuah@unimas.my
}

Shirly Siew-Ling Wong

Faculty of Economics and Business, Universiti Malaysia Sarawak 94300 Kota Samarahan, Sarawak, Malaysia

Mei-Teing Chong

Faculty of Economics and Business, Universiti Malaysia Sarawak 94300 Kota Samarahan, Sarawak, Malaysia

Received: March 2, 2020 Accepted: April 9, 2020 Published: April 15, 2020

doi:10.5296/ber.v10i2.16577ＵRL: https://doi.org/10.5296/ber.v10i2.16577

\begin{abstract}
This paper scrutinised the impact of economic uncertainty on the broad money demand in South Africa using quarterly data from 2001 to 2018. Generalized Autoregressive Conditional Heteroscedasticity $(\mathrm{GARCH})$ model is employed to capture the volatilities of selected components in order to construct an economic uncertainty index (EUI) for South Africa. The constructed index is then used as a regressor along with real income, interest rate and exchange rate in determining South African demand for broad money. The empirical finding
\end{abstract}


using the Autoregressive Distributed Lag approach notably shows that the EUI is negatively affecting South Africa's demand for broad money in the long term. This reveals that economic agents tend to hold real or safer assets than riskier assets, thus reduce broad money demand during times of heightened economy in South Africa. The model is cointegrated in the long-run and stable with the inclusion of EUI in the broad money demand function for South Africa. The findings are able to assist policy makers in using suitable determinants as stabilisation tools and targeting a more effective monetary policy framework refined by appropriate monetary aggregates in South Africa.

Keywords: Economic uncertainty index, Money demand, GARCH, ARDL, South Africa

\section{Introduction}

South Africa is the second-largest economy among the 54 African countries after Nigeria in terms of gross domestic product (GDP). It has been categorized as one of the upper-middle income economies in Sub-Saharan Africa, along with Botswana, Equatorial Guinea, Gabon, Mauritius and Namibia following the World Bank list of economies as of June 2018. Nevertheless, this resource-intensive country is highly vulnerable to turbulence in foreign exchange markets and economic volatility due to its vast capital market exposure. According to Statistics South Africa (2017), the country encountered few significant recessions since the year 1961. In 1990-1992, it faced double-digit inflation as well as deficit on the balance of payments due to capital flight and debt repayment issues. Moreover, South Africa's economic growth experienced several slumps in the aftermaths of the Asian Financial Crisis (1997), South African Currency Crisis (2001), and Global Financial Crisis (mid 2007-early 2009), to name a few.

In 2012, the South African economy was negatively affected by the underperforming economic condition of a neighbouring country, Zimbabwe, and some political issues (Redl, 2018). In fact, Zimbabwe is recognized as important trading partner with South Africa and they have conducted strong bilateral trade since 1964. The main exports of South Africa are machinery products, mineral fuels and oils while the import items from Zimbabwe are gold, platinum and raw tobacco. The growth rate of GDP in 2013 was driven by the manufacturing sector. In 2015, the rand depreciated due to the replacement of the finance minister by President Jacob Zuma. Notably, a depreciation of currency led to inflation and financial uncertainty (Chan et al., 2019). In this case, the confidence of investors was shaken, which further induced an extensive withdrawal of financial assets from South Africa. Based on the report from United Nations Economic Commission for Africa (2017), South Africa faced unfavourable economic conditions including increasing account deficit, slump of oil and commodity prices and the drought issue in 2016. Meanwhile, the report also highlighted that the rand was greatly affected due to the shocks from domestic policy as well as tightening monetary policy.

As one of the leading emerging economies, South Africa is widely vulnerable to exceptional levels of uncertainty in developed countries or other emerging economies (Simo-Kengne et al., 2017). To cope with the economic fluctuations and to achieve price stability, the implementation of a monetary policy targeting monetary aggregates requires a money 
demand function (MDF) that is stable and well-explained. To achieve this, certain factors have been identified that trigger uncertainty in South Africa's economy, as asserted in the study of Atta-Mensah (2004). Thus, this paper suggests including economic uncertainty as one of the factors in the model of money demand for the case of South Africa. By employing the economic uncertainty index variable, it is believed that the estimation of MDF can be improved, which in turn can lead to better establishment of South Africa's monetary policy.

We review the related literature in the following section. The subsequent section explains the data series and methodology, followed by results and discussions. The last section concludes the paper.

\section{Literature Review}

The review of literature is divided into two categories: the basic model (without uncertainty as determinant) and uncertainty model (with uncertainty as determinant). In the basic model, for example, Bahmani-Oskooee and Shabsigh (1996) scrutinised MDF for the case of Japan by incorporating real income, interest rate and exchange rate. Their results showed that the added exchange rate prompted the presence of cointegration in the model. This result corresponds with the studies by Bahmani-Oskooee et al. (1998), Ewing and Payne (1999), Bahmani-Oskooee and Ng (2002) and Sahadudheen (2011). Currently, more researchers are examining asymmetric or symmetric effects of exchange rate on the demand for money, e.g., Bahmani-Oskooee et al. (2017), Mahmood and Alkhateeb (2018), Bahmani-Oskooee and Gelan (2019), and Leong et al. (2019). These research works implied that the incorporation of exchange rate into the conventional MDF is essential. Other than exchange rate, other studies explored this field with other factors or different perspectives. For example, Hiew et al. (2013) and Hiew et al. (2019) tested the traditional MDF with advertising expenditure as a new regressor for the case of Indonesia and Russia. Leong et al. (2010) and Puah et al. (2018) revisited the MDF by comparing simple-sum and Divisia monetary aggregates.

The significance of the inclusion of an economic uncertainty variable in the estimation of MDF is slowly arose due to the instability of money demand in a few studies. Andoh and Chappell (2002) showed that financial reformation in 1983 caused instable money demand in Ghana. Meanwhile, Bahmani-Oskooee and Shin (2002) found that Korea's demand for money was unstable due to the 1997 East Asian Crisis. Thus, in order to capture the shocks or volatilities, Atta-Mensah (2004) recommended incorporating economic uncertainty in the estimation of the money demand model. Furthermore, Lee and Chien (2008) analysed the case in China and found that structural breaks in 1980 and 1993 were mainly caused by the economic and financial crisis. Whilst some researchers have focused on the basic model, few studies have attempted to explore the uncertainty model in recent years. As an example, Jackman (2010) examined the money demand and economic uncertainty in Barbados. Empirically, his finding showed that a negative relationship was found in the long term, which corresponds to the study by Dahmardeh et al. (2011). Their findings also further clarified that a conventional money demand model cannot adequately shed light on the recent behaviour of real monetary aggregates.

Moreover, Fanta (2013) discovered the importance of the economic uncertainty index (EUI). 
After EUI was added into the money demand model, a long-run equilibrium was established between the variables. This finding corresponds with the studies by Bahmani-Oskooee et al. (2013), and Bahmani-Oskooee and Xi (2014). They clarified the vital role of EUI in explaining the recent behaviour of money demand after the financial reforms. In addition, Gan et al. (2015) conducted an empirical analysis that related the money demand with economic uncertainty, proving that an increase in economic uncertainty will induce a decrease in money demand. From here, they suggested that along with EUI, exchange rate and the rate of inflation can serve as important indicators for the establishment of economic policy. According to Bahmani-Oskooee and Baek (2016), money demand is negatively affected by economic uncertainty in both the short- and long-run. Furthermore, Sianturi et al. (2017) proved that the deregulation of financial markets and financial liberalization triggered volatility of money demand. Therefore, economic uncertainty is an important factor in money demand in that it simply influences the behaviour of economic agents in the long-run.

\section{Methodology}

To determine the money demand model for the case of South Africa, an empirical model was established as follows:

$$
L R M 2_{t}=\beta_{0}+\beta_{1} L R G D P_{t}+\beta_{2} L T B R_{t}+\beta_{3} L N E E R_{t}+\beta_{4} E U I_{t}+\varepsilon_{t}
$$

where RM2 stands as the broad money demand in real terms, RGDP denotes real income, TBR symbolises treasury bill rate, NEER represents nominal effective exchange rate, EUI denotes the economic uncertainty index, $\beta_{0}$ indicates the intercept, $\beta_{1}, \beta_{2}, \beta_{3}, \beta_{4}$ represent the estimated coefficients of each regressor, and $\varepsilon_{t}$ denotes the white noise term. The construction of EUI in this paper follows the study by Attah-Mensah (2004). It is constructed with five macroeconomic components, which are RGDP (real economic activity), government bond yield (bond market), Johannesburg stock exchange (stock market), money market rate (monetary policy uncertainty), and bilateral exchange rate (external shocks). The data used are quarterly-based from 2001:Q1 to 2018:Q4 and sourced from International Financial Statistics (IFS).

Few stages are taken to estimate the MDF in South Africa. Firstly, the volatilities of the chosen macroeconomic components of EUI are extracted based on the GARCH $(1,1)$ model, which originated from the GARCH (p, q) model developed by Bollerslev et al. (1992). The computed volatilities of each component are standardised as the deviation from its mean and divided by the standard deviation. Then, the EUI is constructed following the study by Attah-Mensah (2004) as a weighted average of the estimated volatilities. Subsequently, unit root tests such as Augmented Dickey-Fuller (ADF) test and Phillips-Perron (PP) test are implemented to examine the stationarity of each variable. After that, the model as seen in Equation (1) is tested using the Autoregressive Distributed Lag (ARDL) approach by Pesaran et al. (2001) and the specification of the model can be written as:

$$
\begin{gathered}
\Delta L R M 2_{t}=\beta_{0}+\sum_{i=1}^{p} \alpha_{i} \Delta L R M 2_{t-i}+\sum_{i=0}^{p} \gamma_{i} \Delta L R G D P_{t-i}+\sum_{i=0}^{p} \delta_{i} \Delta L T B R_{t-i}+\sum_{i=0}^{p} \varphi_{i} \Delta L N E E R_{t-i}+\sum_{i=0}^{p} \tau_{i} \Delta E U I_{t-i} \\
+\theta_{1} L R M 2_{t-1}+\theta_{2} L R G D P_{t-1}+\theta_{3} L T B R_{t-1}+\theta_{4} L N E E R_{t-1}+\theta_{5} E U I_{t-1}+\omega_{t}
\end{gathered}
$$


where $\Delta$ is the first difference operator and $\omega$ represents the error term. Real income carries a positive sign while the interest rate carries a negative sign. However, Kapingura (2014) opined that the interest rate might be attached with a positive sign. Mundell (1963) argued that the additional crucial factor of money demand is the exchange rate, and they can be positively or negatively related. The recent discovery of financial innovations as well as uncertainties implies that a simple relationship of the traditional MDF might be inadequate to explain the recent behaviour of the monetary aggregates. Hence, a revised MDF was proposed by Atta-Mensah (2004), which included an EUI that can capture the economic uncertainty. When economic uncertainty heightens, people will tend to reduce broad money demand and retain real assets instead of nominal assets.

\section{Empirical Results and Discussions}

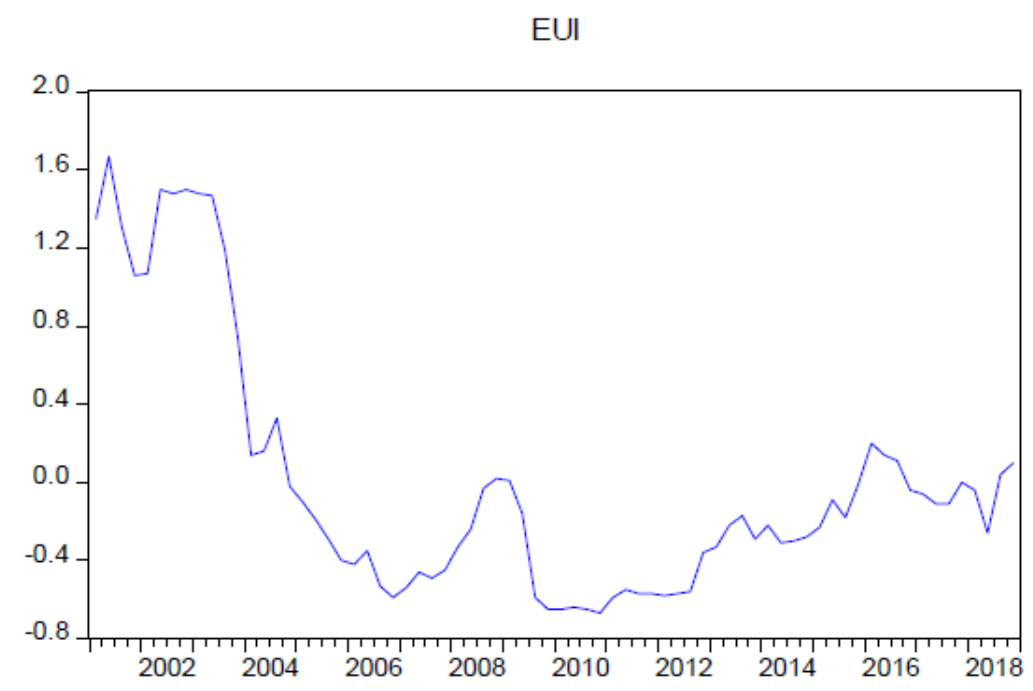

Figure 1. The Economic Uncertainty Index (EUI) for South Africa

Figure 1 displays the constructed EUI for South Africa from 2001:Q1 to 2018:Q4. There are few noticeable heightened levels of economic fluctuations during this period. For example, the Currency Crisis (2001) and the heightened level of volatility in the bond market as well as stock market in 2001:Q2 caused the peak of the EUI at that particular time. The slow recovery from the crisis and economic slowdown during the period between 2001:Q2 and 2011:Q1 was reflected in the instability on real economic activity. Under the event of 2008 Global Financial Crisis, EUI indicates that the economy of South Africa encountered a heightened level in 2008:Q4.

In addition, the increase in the volatility of both monetary policy and bond market triggered the level of economic uncertainty in South Africa to elevate. A peak of uncertainty was again reached during 2016:Q2 due to the heightened level of volatility in bond markets, stock markets and external shocks. The factors of poverty, high unemployment rate as well as sluggish economic activity caused a lack of confidence for investors, and hence dampened the performance of the stock market. Notably, the constructed EUI captured most of the 
periods that experienced high volatility (uncertainty) from the diverse markets in South Africa.

Table 1 indicates the findings generated from the estimations of unit root tests. A combination of level and first difference properties exhibits among the variables. The analysis also evidently shows non-existent of second difference properties.

Table 1. Unit Root Test Results

\begin{tabular}{|l|c|l|l|l|}
\hline \multirow{2}{*}{ Series } & Test Statistics & \multicolumn{5}{l|}{} \\
\cline { 2 - 5 } & $\mathbf{t}_{\mu}$ & $\mathbf{t}_{\tau}$ & $\eta_{\mu}$ & $\eta_{\tau}$ \\
\hline Panel A: Level & \multicolumn{5}{|l|}{} \\
\hline LRM2 & $-2.809(4)^{*}$ & $-1.678(4)$ & $-3.157(3)^{* *}$ & $-1.163(4)$ \\
\hline LRGDP & $-2.109(4)$ & $-1.068(4)$ & $-5.412(57)^{* * *}$ & $-0.625(26)$ \\
\hline LTBR & $-2.348(1)$ & $-2.534(1)$ & $-1.836(3)$ & $-1.789(3)$ \\
\hline LNEER & $-1.134(1)$ & $-2.585(1)$ & $-1.045(3)$ & $-2.331(3)$ \\
\hline EUI & $-2.130(0)$ & $-1.349(0)$ & $-2.130(0)$ & $-1.447(1)$ \\
\hline Panel B: First Difference & \multicolumn{5}{|l}{} \\
\hline$\Delta$ LRM2 & $-3.565(2)^{* * *}$ & $-4.525(2)^{* * *}$ & $-7.160(1)^{* * *}$ & $-7.708(6)^{* * *}$ \\
\hline$\Delta$ LRGDP & $-6.097(2)^{* * *}$ & $-7.332(2)^{* * *}$ & $-8.831(7)^{* * *}$ & $-11.667(25)^{* * *}$ \\
\hline$\Delta$ LTBR & $-4.490(0)^{* * *}$ & $-4.507(0)^{* * *}$ & $-4.243(6)^{* * *}$ & $-4.245(6)^{* * *}$ \\
\hline$\Delta$ LNEER & $-6.615(0)^{* * *}$ & $-6.570(0)^{* * *}$ & $-6.565(2)^{* * *}$ & $-6.518(2)^{* * *}$ \\
\hline$\Delta$ EUI & $-6.823(0)^{* * *}$ & $-7.248(0)^{* * *}$ & $-6.869(2)^{* * *}$ & $-7.253(3)^{* * *}$ \\
\hline
\end{tabular}

Notes: The $\mathrm{t}$ and $\eta$ statistics are for $\mathrm{ADF}$ and PP, respectively. The subscript $\mu$ in the model refers to the intercept in the model while $\tau$ refers to the trend and intercept in the model. Asterisks $(* * *),(* *)$ and $(*)$ indicate statistically significant at $1 \%, 5 \%$ and $10 \%$ levels, respectively. Figures in parentheses are the lag lengths for ADF and bandwidths for PP. $\Delta$ denotes first difference operator. Both ADF and PP tests examine the null hypothesis of a unit root against the stationary alternative.

Then, we proceed to ARDL bound tests. The computed $F$-statistic is 5.173, exceeding the critical value of 3.29 (lower bound) and 4.37 (upper bound) as in Pesaran et al. (2001) and thus is statistically significant at 1 percent level. Therefore, a long-run relationship is well-established among the variables. Moreover, the existence of a long-run relationship can be reconfirmed through error correction term $(\mathrm{EC})$. The coefficient of lagged $\mathrm{EC}\left(\mathrm{EC}_{\mathrm{t}-1}\right)$ obtained from the study is -0.841 , in negative sign and less than unity, as well as statistically significant at 1 percent level with a $t$-statistics of -6.065 . Hence, we can reaffirm that a cointegration relationship does exist in the model.

In addition, Table 2 tabulates the outcomes of long-run elasticity and short-run causality estimations with a series of diagnostic checking. The empirical findings disclose that LTBR, LNEER and EUI are statistically significant at 1 percent level while LRGDP is statistically significant at 5 percent level. The positive association between LRGDP and LRM2 is in line with a priori theory of money demand. When real income increases, purchasing power of 
consumers will be boosted and thus, increasing the demand for money. However, it is noteworthy that LTBR is positively related with LRM2. The increasing demand for money from the soaring interest rate can be dominated by the wealth effect on the rate of return; such a case is supported by Kapingura (2014). It indicates that a rise of rate of return enhances the wealth effect, hence people will spend more by demanding more money. Looking at the exchange rate, a negative relationship between LNEER and LRM2 can be explained by the currency substitution effect in South Africa. Foreign currency is more attractive to hold, given the condition of further depreciation of domestic currency in South Africa.

Table 2. Estimations of Long-run Elasticity, Short-run Causality and Diagnostic Tests

\begin{tabular}{|l|l|l|}
\hline \multicolumn{3}{|l|}{ Panel A: Long-run Elasticity (Model: 3, 6, 4, 9,9) } \\
\hline Regressor & Coefficient & t-statistics \\
\hline LRGDP & $0.564^{* *}$ & 2.599 \\
\hline LTBR & $0.178^{* * *}$ & 8.733 \\
\hline LNEER & $-0.328^{* * *}$ & -2.744 \\
\hline EUI & $-0.187^{* * *}$ & -4.113 \\
\hline C & $5.740^{* *}$ & 2.342 \\
\hline Panel B: Short-run Causality Tests (Dependent Variable: LRM2) \\
\hline Regressor & $\boldsymbol{F}$-statistics & $\boldsymbol{p}$-value \\
\hline LRGDP & $3.595^{* *}$ & 0.010 \\
\hline LTBR & 1.263 & 0.309 \\
\hline LNEER & $2.418^{* *}$ & 0.037 \\
\hline EUI & $2.940^{* *}$ & 0.014 \\
\hline Panel C: Diagnostic Tests & \\
\hline JB & $1.732(0.421)$ & \\
\hline AR [2] & $2.607(0.272)$ & \\
\hline ARCH [1] & $0.042(0.837)$ & \\
\hline RESET [1] & $1.868(0.183)$ & \\
\hline CUSUM & Stable & \\
\hline CUSUM & Stable &
\end{tabular}

Notes: JB stands for Jarque-Bera statistic in order to test for normality. AR[2] is defined as the 2nd order serial correlation, a part of the Lagrange Multiplier test by employing the Breusch-Godfrey serial correlation. ARCH [1] is explained as 1st order of ARCH heteroscedasticity test. RESET refers the test of Ramsey RESET for the estimation of any misspecification. CUSUM stands for cumulative sum of recursive residuals stability test while CUSUM2 represents cumulative sum of squares of recursive residuals stability test. Figures in the parentheses are the $p$-values. Asterisks $(* * *),(* *)$ and $(*)$ denote significant at $1 \%, 5 \%$ and $10 \%$ levels, respectively.

The negative sign of EUI conforms to the theoretical expectation that economic agents tend to hold alternative valuable assets (e.g., gold, diamond or real estate) instead of nominal assets when the economy is in an uncertain condition. This finding is in line with the study by Atta-Mensah (2004), in which the broad money such as mutual funds are less favorable to 
hold by risk-averse agents during the heightened economic uncertainty in the long-run period, while narrow money such as money balances is perceived to be favorable in the short-run as the results of precaution motives. In the short-run, only LRGDP, LNEER and EUI do Granger-cause LRM2. However, an absence of short-run causality effects running from LTBR to LRM2 is revealed. The model passes all the diagnostic tests, which consists of normality, serial correlation, heteroskedasticity and functional form tests. Moreover, this model is stable when CUSUM and CUSUM of square tests were applied. Therefore, a stable MDF has been derived for South Africa. The achievement of the stability may due to the inclusion of EUI that able to capture the economic uncertainty condition for the period of study.

\section{Conclusion}

The aim of the current study was to examine the MDF of South Africa by introducing EUI as a new regressor into the model. It is commonly known that the fundamental of an effective monetary policy needs a MDF that is stable and well-explained. This study found that both the ARDL bounds test and lagged EC indicate that the empirical model has a long-run relationship. The model is proved robust as it passes all the diagnostic tests. Therefore, a stable South African money demand model is well-established. The determinants used in the empirical model can be utilised as stabilisation tools for a real broad monetary aggregate by South African monetary authorities. The presence of a stable broad money demand model with the inclusion of EUI further supports the idea that the traditional MDF can be periodically improved or developed with determinants other than a priori theory to better assess the situation. Future studies may consider to include EUI in the estimation of MDF for other countries. Also, the components of EUI could include alternative components, such as commodity price, inflation rate and so on, depending on the country's context.

\section{References}

Andoh, S. K., \& Chappell, D. (2002). Stability of the money demand function: Evidence from Ghana. Applied Economics Letters, 9(13), 875-878.

https://doi.org/10.1080/13504850210158971

Atta-Mensah, J. (2004). Money demand and economic uncertainty. Bank of Canada Working Paper, No. 2004-25.

Bahmani-Oskooee, M., \& Baek, J. (2016). Economic uncertainty, monetary uncertainty and the Korean demand for money. Journal of Economic Policy Reform, 20(1), 86-97.

https://doi.org/10.1080/17487870.2016.1213166

Bahmani-Oskooee, M., \& Gelan, A. (2019). Asymmetric effects of exchange rate changes on the demand for money in Africa. Applied Economics, 51(31), 3365-3375.

https://doi.org/10.1080/00036846.2019.1578854

Bahmani-Oskooee, M., Halicioglu, F., \& Bahmani, S. (2017). Do exchange rate changes have symmetric or asymmetric effects on the demand for money in Turkey? Applied Economics, 49(42), 4261-4270. https://doi.org/10.1080/00036846.2017.1279271 
Bahmani-Oskooee, M., Kutan, A. M., \& Xi, D. (2013). The impact of economic and monetary uncertainty on the demand for money in emerging economies. Applied Economics, 45(23), 3278-3287. https://doi.org/10.1080/00036846.2012.705430

Bahmani-Oskooee, M., Martin, M. A. G., \& Niroomand, F. (1998). Exchange rate sensitivity of the demand for money in Spain. Applied Economics, 30(5), 607-612.

https://doi.org/10.1080/000368498325598

Bahmani-Oskooee, M., \& Ng, R. C. W. (2002). Long-run demand for money in Hong Kong: An application of the ARDL model. International Journal of Business and Economics, 1(2), 147-155.

Bahmani-Oskooee, M., \& Shabsigh, G. (1996). The demand for money in Japan: Evidence from cointegration analysis. Japan and the World Economy, 8(1), 1-10.

https://doi.org/10.1016/0922-1425(95)00002-x

Bahmani-Oskooee, M., \& Shin, S. W. (2002). Stability of the demand for money in Korea. International Economic Journal, 16(2), 85-95. https://doi.org/10.1080/10168730200080015

Bahmani-Oskooee, M., \& Xi, D. (2014). Economic uncertainty, monetary uncertainty, and the demand for money: Evidence from Asian countries. Australian Economic Papers, 53(1-2), 16-28. https://doi.org/10.1111/1467-8454.12018

Bollerslev, T., Chou, R., \& Kroner, K. F. (1992). ARCH modeling in finance: A review of the theory and empirical evidence. Journal of Econometrics, 52(1-2), 5-59.

https://doi.org/10.1016/0304-4076(92)90064-X

Chan, T. H., Puah, C. H., \& Wong, S. S. L (2019). Exchange rates, monetary aggregates, industrial production and shock adjustments in Malaysia after the capital control. International Journal of Business \& Society, 20(1), 95-110.

Dahmardeh, N., Pourshahabi, F., \& Mahmoudinia, D. (2011). Economic uncertainty - money demand nexus in Iran application of the EGARCH model and the ARDL approach. European Journal of Economics, Finance and Administrative Sciences, 38, 118-126.

Ewing, B. T., \& Payne, J. E. (1998) Some recent international evidence on the demand for money. Studies in Economics and Finance, 19(2), 84-107. https://doi.org/10.1108/eb028754

Fanta, F. (2013). Financial deregulation, economic uncertainty and the stability of money demand in Australia. Economic Papers, 32(4), 496-511.

https://doi.org/10.1111/1759-3441.12058

Gan, P. T., Lim, S. Y., Mohd Hussin, M. Y., \& Muhammad, F. (2015). Empirical analysis of money demand function with economic uncertainty. International Jounal of Economics and Financial Issues, 5(1S), 98-105.

Hiew, L. C., Puah, C. H., \& Habibullah, M. S. (2013). The role of advertising expenditure in measuring Indonesia's money demand function. The Journal of American Business Review, Cambridge, 2(1), 130-137. 


\section{Mll Macrothink}

Business and Economic Research ISSN 2162-4860 2020, Vol. 10, No. 2

Hiew, L. C., Puah, C. H., Arip, M. A., \& Chong, M. T. (2019). Role of advertising expenditure as an influential non-traditional regressor in Russia's money demand specification. International Journal of Financial Research, 10(6), 232-240.

https://doi.org/10.5430/ijfr.v10n6p232

Jackman, M. (2010). Money demand and economic uncertainty in Barbados. Munich University Library - Munich Personal RePEc Archive (MPRA), Paper No. 34561.

Kapingura, F. M. (2014). The stability of the money demand function in South Africa: A VAR-based approach. International Business \& Economics Research Journal, 13(6), 1471-1482. https://doi.org/10.19030/iber.v13i6.8935

Lee, C. C., \& Chien, M. S. (2008). Stability of money demand function revisited in China. Applied Economics, 40(24), 3185-3197. https://doi.org/10.1080/00036840600994153

Leong, C. M., Puah, C. H., Abu Mansor, S., \& Lau, E. (2010). Testing the effectiveness of monetary policy in Malaysia using alternative monetary aggregation. Margin - The Journal of Applied Economic Research, 4(3), 321-338. https://doi.org/10.1177/097380101000400304

Leong, C. M., Puah, C. H., Lau, E., \& Abu Mansor, S. (2019). Asymmetric effects of exchange rate changes on the demand for divisia money in Malaysia. Journal of International Studies, 12(4), 52-62. https://doi.org/10.14254/2071-8330.2019/12-4/4

Mahmood, H., \& Alkhateeb, T. T. Y. (2018). Asymmetrical effects of real exchange rate on the money demand in Saudi Arabia: A non-linear ARDL approach. PLOS ONE, 13(11), 1-12. https://doi.org/10.1371/journal.pone.0207598

Mundell, R. A. (1963). Capital mobility and stabilization policy under fixed and flexible exchange rates. Canadian Journal of Economics and Political Science/Revue Canadienne De Economiques Et Science Politique, 29(4), 475-485. https://doi.org/10.2307/139336

Pesaran, M. H., Shin, Y., \& Smith, R. J. (2001). Bounds testing approaches to the analysis of level relationships. Journal of Applied Econometrics, 16(3), 289-326.

https://doi.org/10.1002/jae.616

Puah, C. H., Leong, C. M., Mansor, S. A., \& Lau, E. (2018). Revisiting money demand in Malaysia: Simple-sum versus Divisia monetary aggregates. Jurnal Ekonomi Malaysia, 52(2), 267-278. http://dx.doi.org/10.17576/JEM-2018-5202-21

Redl, C. (2018). Macroeconomic uncertainty in South Africa. South African Journal of Economics, 86(3), 361-380. https://doi.org/10.1111/saje.12198

Sahadudheen, I. (2011). Demand for money and exchange rate: Evidence for wealth effect in India. Undergraduate Economic Review, 8(1), 1-15.

Sianturi, R., Tanjung, A., Leong, C. M., Puah, C. H., \& Brahmana, R. K. (2017). Financial liberalization and Divisia money demand in Indonesia. Advanced Science Letters, 23(4), 3155-3158. https://doi.org/10.1166/asl.2017.7683

Simo-Kengne, B. D., Ababio, K. A., Mba, J., Koumba, U., \& Molepo, M. (2017). Risk, 


\section{Macrothink}

Business and Economic Research

ISSN 2162-4860 2020, Vol. 10, No. 2

uncertainty and exchange rate behavior in South Africa. Journal of African Business, 19(2), 262-278. https://doi.org/10.1080/15228916.2017.1413627

Statistics South Africa. (2017, Novemeber 17). African Statistics Day 2017: 4 facts about our economy. [Online] Available: http://www.statssa.gov.za/?p=10718

United Nations Economic Commission for Africa. (2017). Economic Report on Africa 2017: Urbanization and Industrialization for Africa's Transformation. Addis Ababa, Ethiopia: Economic Commission for Africa.

\section{Copyright Disclaimer}

Copyright for this article is retained by the author(s), with first publication rights granted to the journal.

This is an open-access article distributed under the terms and conditions of the Creative Commons Attribution license (http://creativecommons.org/licenses/by/4.0/). 